в непосредственной связи с нервами другой почки. Такими анатомическими данными автор об'ясняет некоторые совершенно непонятные, на первый взгляд, к.линические явления: почечно-почечный реблекс, реблекторные боли в отдаленных областях и т. П.

И. Iцимиес.

\title{
б) Фоизиология.
}

402. Роль печени в оолмене водьь. L e n a z (Klin. Woch.. 1926. № 10) считает неправильным взгляд L a m s o n’a, R o c a и др., приписывающих печени больпую роль в обмене воды, об'ясняя это существованием в ней запирающего механизма, ғоторый, благодаря сокращению v. hepaticae, регулирует поступление воды в кровь. Он полагает, что регуляция воды зависит от равновесия между осмотическим давлением плазмы и капиллярным кровяным давлением; при этом чрезмерное прибавление воды вызывает понижение первого по сравнению со вторым, и до достижения равновесия происходит больтрация в перикапиллярные пространства. Если же, благодаря усиленному диурезу, равновесие нарушается в обратную сторону, то вода извлекается из тканей в кровь. Водохранилищем является соединительная ткань. Печень же играет особую роль при подвозе воды per os: при этом увеличивается содержание воды в портальной системе, и избыток ее фильтруется в пери-капиллярные пространства, концентрация же грови в V. hepatica остается такою же, как и во всей сосудистой системе. Только при первичном изменении осмотического давления плазмы или при изменении давления в капиллярах может наступить избыток воды в крови.

\section{Э. Р. Могилевский}

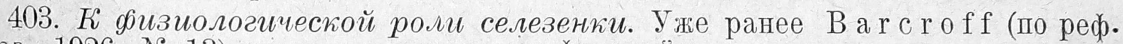
Вр. Газ., 1926, № 13) указал, что одною из бункций селезенки является сохранение ело запаса эритроцитов, поторый в известные моменты, 一 после кровоизлияний, сильных мышечных упражнений и др. случаев нүжды в гэмоглобине,-опорожняется в общий поток кровообращения, что сказывается довольно резким уменьщением об'ема этого органа. Интересно, что этот хранящийся в селезенке запас эритроцитов тораздо менее уязвим для различных токсических веществ, чем эритроциты, циркулирующие в общем потоке кровообращения. Дальнейпие наблюдения автора, произведенные через целлулоидное окошечко в брюшной стенке, подтвердили, что действительно об'ем селезенки после мыпечных усилий и кровопусканий уменьпается до 1/3--1/2 первоначального об'ема. Исследуя затем запасную кровь, хранящуюся в селезенке и опоражниваемую ею в случае нужды, $B$. нашел, что она гораздо богаче гэмоглобином и эритроцитами, чем кровь в общем потоке кровообращения. Наконец, $B$. подметил у селезенки способность значительно увеличиваться в об'еме под влиянием усиленной доставки жидкости в кровь: повидимому, селезенка является приспособительным аппаратом для облегчения и регулирования работы сердца, каковой аппарат приводится в действие через посредство реблекторного механизма $n$. depressoris.

B. Сергеев.

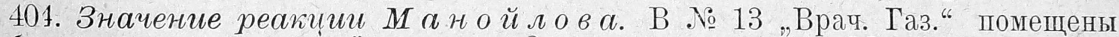
две работы, посвященные этой реакции. Одна, принадлежащая М. Я. Г а л в я л 0 ,

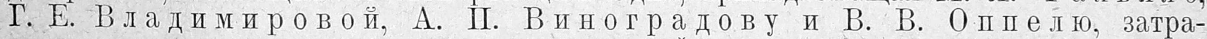
гивает вопрос о химизме реакции и ее специфичности, другая, авторами которой являются А. А. ІІІ м и д т и Н. О. П е р е в з с к а я, посвящена вопросу о бизиолого-химическом обосновании ее. Авторы первой работы приходят к заключению, что реағция $\boldsymbol{M}$. неспецифбична, и, при богатых белками биологических жидкостях (кровь, кровяная сыворотка и т. д.), результаты ее обусловливаются почти исключительно содержанием белков в этих жидкостях. Авторы второй работы указывают, что женская сыворотка содержит на 8,5\% больше белков, чем мужская, и там, тде реакция правильно указывает на пол, это зависит не от присутствия в кровяной сыворотке гормонов половых желез, а от того или другого содержания в ней белғїв.

\section{b) общкая nатология.}

B. $C$.

405 Віияние безвитаминного питания на рост опухолей изучал $\mathrm{L} \mathrm{u} \mathrm{d}-$ w ig (Arch. f. G., Bd. 125) и убедился, что мыши, получавшие безвитаминную пищу, менее восприимчивы к раку. На развившуюся уже опухоль диэта влияния не оказывает. Подобные же данные получились при опытах с прививкой саркомы у крыс-в 35,7\% опухоль вообще при этих условиях не прививается, в $64,3 \%$ она ростет медленнее и позднее убивает животное.

A. $T$.

406. Зависимость развития рака оm характера питания Hindhede (Ber. uiber dù gesam. Gyn., Bd. IX) наблюдал в Дании. Народы с вегетерианским 